\title{
Anthropogenic Ties to Late-Successional Structure and Composition in Four New England Hemlock Stands
}

\section{Citation}

McLachlan, Jason S., David R. Foster, and Fabian Menalled. 2000. Anthropogenic Ties to LateSuccessional Structure and Composition in Four New England Hemlock Stands. Ecology 81, no. 3: 717. doi:10.2307/177372.

\section{Published Version}

doi:http:10.2307/177372

\section{Permanent link}

http://nrs.harvard.edu/urn-3:HUL.InstRepos:30673720

\section{Terms of Use}

This article was downloaded from Harvard University's DASH repository, and is made available under the terms and conditions applicable to Other Posted Material, as set forth at http:// nrs.harvard.edu/urn-3:HUL.InstRepos:dash.current.terms-of-use\#LAA

\section{Share Your Story}

The Harvard community has made this article openly available.

Please share how this access benefits you. Submit a story.

\section{Accessibility}




\title{
ANTHROPOGENIC TIES TO LATE-SUCCESSIONAL STRUCTURE AND COMPOSITION IN FOUR NEW ENGLAND HEMLOCK STANDS
}

\author{
Jason S. Mclachlan, ${ }^{1}$ David R. Foster, and Fabian Menalled ${ }^{2}$ \\ Harvard Forest, Harvard University, P.O. Box 68, Petersham, Massachusetts 01366 USA
}

\begin{abstract}
The pace and magnitude of long-term change in the forests of eastern North America is poorly understood. The current study examines the developmental history of primary Tsuga canadensis stands in central Massachusetts from before European settlement to the present. Through an integrated reconstructive approach employing stand-level pollen stratigraphies, tree ring chronologies, and long-term archival records, we show how the characteristic structure and composition of old-growth forests in southern New England developed in four stands through a history of anthropogenic and natural disturbance, rather than through the gradual process of autogenic succession. Forest composition during presettlement times was distinct at each site and included a variety of successional stages ranging from late-successional northern hardwood-Tsuga assemblages to assemblages dominated by early successional to mid-successional taxa such as Castanea, Quercus, and Pinus. Anthropogenic disturbance during the 18th and 19th centuries resulted in novel assemblages dominated by Castanea or Betula. Composition at the four sites converged on the current assemblage dominated by large, late-successional Tsuga, in response to altered patterns of disturbance in the 20th century. The age of the dominant trees (100-200 yr) and apparent stability of the current forests masks the extent to which their origin is a product of the cultural landscape and is in no way representative of pre-European forests at these sites.
\end{abstract}

Key words: anthropogenic disturbance; autogenic succession; dendroecology; forest dynamics; paleoecology; Tsuga canadensis.

\section{INTRODUCTION}

Ecologists have increasingly realized that a more detailed understanding of long-term patterns of forest change, and the forces behind that change, is necessary for understanding the structure and function of modern forest ecosystems and the potential impact of current stresses on these systems (Foster 1995, Likens et al. 1996). Basic information is needed on the pace and magnitude of change in forests, on the interaction of multiple disturbances and stresses in forests, and on the limits of forest plasticity in response to a changing environment. Unfortunately, even highly dynamic forests change at a rate that may be imperceptible to human observers, making analysis of long-term change difficult.

A variety of approaches have been employed to resolve this problem, ranging from analyses of historical data (Whitney 1994, Foster et al. 1998), to tree ring and fossil pollen records (Parshall 1995, Fuller et al. 1998), to modeling efforts (Pacala et al. 1996). In the northeastern United States, studies of old-growth forests, in particular, have been increasingly used to draw conclusions about the ecological processes underlying

Manuscript received 12 June 1998; revised 31 December 1998; accepted 17 February 1999.

${ }^{1}$ Present address: Department of Botany, Duke University, Durham, North Carolina 27708 USA.

${ }^{2}$ Present address: Department of Entomology and Pesticide Research Center, Michigan State University, East Lansing, Michigan 48824 USA. long-term forest change (Lorimer and Frelich 1994, Dunwiddie et al. 1996). The motivation for such studies is often to establish a baseline understanding of forest dynamics unaffected by human impact or even unaffected by exogenous disturbance (Runkle 1981). Pacala et al. (1996), for instance, point to the abundance of the late-successional species Tsuga canadensis and $\mathrm{Fa}$ gus grandifolia in old-growth stands as support for the results of SORTIE, a stand simulation model that predicts dominance of these taxa after hundreds of years of uninterrupted succession. Studies that emphasize the long-term resolution of subtle interspecific trade-offs in forest succession often depict the development of eastern old-growth forests as a slow approach to equilibrium conditions in a stable environment (Frelich et al. 1993, Pacala et al. 1996).

But how common are stable conditions in old-growth forests? Such conditions seem to have characterized some forests, such as presettlement northern hardwood forests (Davis et al. 1994, 1998), but reconstructions of the historical development of old-growth stands, using tree rings, historical data and stand-level pollen records, often reveal that the ecological features considered to indicate development under an unchanging environment (e.g., large and old late-successional trees, open understories, and accumulations of coarse woody debris) are in fact the legacy of repeated intense, often anthropogenic, disturbance (Bormann and Buell 1964, Henry and Swan 1974, Patterson and Foster 1990, Nowacki and Abrams 1994, Abrams and Orwig 1996, Fos- 


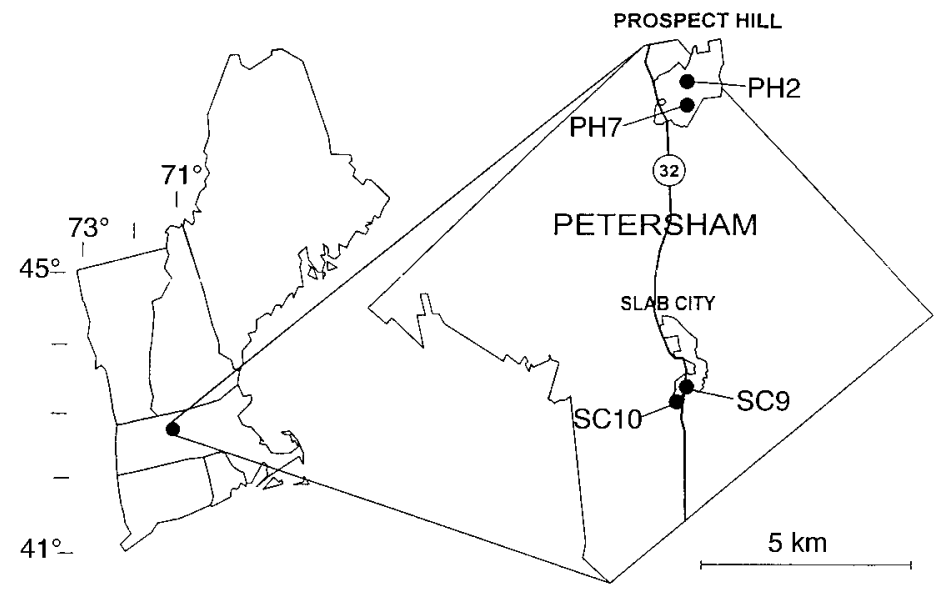

FIG. 1. Location of study sites within the Slab City and Prospect Hill tracts of the Harvard Forest, Petersham, Massachusetts, USA.

ter et al. 1996). Such research suggests that the baseline model for long-term development of old-growth forests in the Northeast needs to be broadened to accommodate a much wider range of historical forces. The current study provides a detailed example of the development of the characteristic structure and composition of oldgrowth forests in southern New England through a dynamic history of anthropogenic and natural disturbance, rather than through the gradual process of autogenic succession.

We employed an integrative approach to reconstruct the postsettlement structural and compositional development of four mature Tsuga canadensis stands in central Massachusetts, using stand-level pollen stratigraphies, tree ring chronologies, and historical records. By using this combination of approaches, the weaknesses of one technique are compensated for by the strengths of the others to produce an unusually complete developmental history. High resolution stand-level pollen records, for instance, can trace many hundreds of years of stand compositional development (Davis et al. 1994), and document the impact of changing land use on stand composition and ecosystem properties (Szeicz et al. 1998). They cannot provide specific information on the disturbance processes behind that compositional change and the structural changes that accompany it. Tree ring records, on the other hand, can provide detailed records of stand development and disturbance histories extending back to presettlement times (Nowacki and Abrams 1994, Abrams and Orwig 1996). Unlike pollen records, however, they lose resolution as they go back in time, and are unable to resolve stand composition accurately before the most recent large disturbance. Both approaches allow only speculative assignments of the identity of specific disturbances, and of the broader cultural and physical context in which they occur, without independent historical information. Fortunately, our study sites are located in a research forest with almost $100 \mathrm{yr}$ of active research into forest history.
Our study sites characterize some of the complexities of the modern New England landscape. On the one hand, the dominance of large old Tsuga canadensis and emergent Pinus strobus in these forests gives the impression of great age and stability, described by one prominent ecologist who studied our Slab City X site in the 1930s as "answer[ing] the description of the climax" (H. Raup, unpublished data). On the other hand, historical evidence and the results of previous studies (Spurr 1950, Foster et al. 1992) indicate that these are not, in fact, old-growth but primary forests: representing the $15 \%$ of the landscape that was never cleared for agriculture, but which has a history of forest cutting (Foster 1992, Peterken 1996). The goals of our investigation were to: (1) determine the extent and variability of change in some of the oldest and least disturbed forests on the modern landscape, from presettlement times to the present; (2) evaluate the relative impact of various natural and anthropogenic disturbance processes on long-term structural and compositional dynamics of these stands; and (3) consider the successional role of tree species in such stands. Because the four stands we investigated are currently similar in composition and structure, we were able to illustrate the range of disturbance histories capable of producing this unusual assemblage.

\section{Study AREA}

\section{Physical and cultural setting}

The study sites are located in Petersham, Massachusetts (Fig. 1), in the central uplands of Massachusetts, an area of undulating topography with low north-south ridges $150-300 \mathrm{~m}$ above sea level. The area receives $\sim 100 \mathrm{~cm}$ of rain, distributed evenly throughout the year, with an average growing season of $138 \mathrm{~d}$. Shallow till soils in the region are acidic and relatively unproductive. The area lies in the transition hardwood zone (Westveld 1956), made up of a mixture of northern hardwoods such as Fagus grandifolia, Acer saccharum, 
and Betula alleghaniensis with Tsuga canadensis, Acer rubrum, Pinus strobus, and more southern species such as Quercus rubra and Castanea dentata.

During presettlement times, fire-sensitive species such as Tsuga canadensis and Picea rubens appear to have been most common in low protected areas of the central uplands (Foster and Zebryk 1993), while species such as Quercus rubra and Castanea dentata may have occurred on drier exposed sites (Whitney 1793). The dominant natural disturbance appears to have been catastrophic wind storms (Foster and Boose 1992), although fire and pathogens were also important factors. The importance of Native American land use, particularly fire, on presettlement vegetation is the subject of vigorous debate (Russell 1983, Whitney 1994). Although Native Americans used upland areas in central New England for hunting and seasonal village sites, there is currently no evidence that they influenced forest structure or composition through fire, village development, or agriculture (Patterson and Backman 1988, Patterson and Sassaman 1988, Bragdon 1996, Fuller et al. 1998; M. Mulholland, personal соттиnication). Nearby low-elevation areas such as the Connecticut River Valley had higher proportions of Castanea dentata, and Quercus and Pinus spp. before European settlement. This compositional difference is correlated with higher Native American population densities as well as with climatic and edaphic trends favoring these more southern species (Fuller et al. 1998). Regional trends in forest composition, therefore, raise interesting questions about which ecological mechanisms allowed the persistence of taxa characteristic of low elevations in our upland study area.

European settlement occurred in the 1730s and forest clearing for agriculture proceeded until nearly $85 \%$ of the township was open land in 1850 (Foster 1992). Agricultural abandonment began in the mid-19th century, as the township's population migrated to urban industrial areas or to the agricultural Midwest. From 1912 to 1914, the chestnut blight (Endothia parasitica) completely eliminated Castanea dentata from the forest canopy (Kittredge 1917). In 1938, a major hurricane, and subsequent salvage operations, reduced the standing timber volume at the Harvard Forest by $~ 70 \%$ (Brake and Post 1941). The township is now nearly $90 \%$ forested and dominated by moderately shade-tolerant sprouting species such as Acer rubrum, Betula lenta, and Quercus rubra.

\section{Study sites}

Among the mature primary Tsuga canadensis stands available for study, four were selected based on Harvard Forest records, which indicated that they were among the oldest and least disturbed sites, and on the length and quality of the humus pollen record they contained. The stands occupy a range of physiographic locations on the Prospect Hill and Slab City tracts of the Harvard Forest, and are among the least disturbed forests in the township. All four stands have very sparse understory vegetation, presumably due to the deep shade and thick acidic humus layer produced by the dominant Tsuga canadensis. Their overstory compositions are discussed in greater detail in the Results section under Modern stand characteristics and recent stand development. Slab City IX is in a stand of large Tsuga canadensis and Pinus strobus on a steep eastfacing hillside. Although the stand was described as having "the characteristics of a climax stand" in 1942 (Harvard Forest, unpublished manuscript), the presence of dead Castanea dentata and Betula papyrifera suggest that it has a history of disturbance. Its soil is a well-drained Charlton stony fine sandy loam, in glacial till derived from granites and gneisses. Slab City $\mathrm{X}$ is located in a nearby poorly drained area, part of which has ponded surface water during the spring. The stand has a canopy dominated by Tsuga canadensis shared with straight-stemmed Quercus rubra, Acer rubrum, and Fagus grandifolia, with large Pinus strobus emerging above the canopy. Soil at this site is classified as a Sudbury fine sandy loam, a granitic outwash soil with restricted internal drainage due to a seasonally high water table. Prospect Hill II is on a flat site whose soils are classified as Gloucester stony loam, a somewhat excessively drained soil formed in granitic glacial till. The site is dominated by Tsuga canadensis and Pinus strobus whose massive stems stand out even in the large tract of primary forest in which it is located (see Plate 1). The site is referred to as "old-growth" in the earliest Harvard Forest archival records (1907). Prospect Hill VII is located on a gentle hill slope whose soils are also classified as a Gloucester stony loam. The presence of cut stumps and Castanea dentata poles at the site indicate a more recent history of forest cutting at the site, although its canopy of Tsuga canadensis and Quercus rubra are noticeably more mature than surrounding stands.

\section{Methods}

\section{Modern stand characteristics and historical data}

We recorded species, diameter at breast height (dbh $=135 \mathrm{~cm}$ ), and crown class for all individuals $>2.5$ $\mathrm{cm}$ in basal diameter in a $30 \times 30 \mathrm{~m}$ plot in each stand centered around the site of the humus monolith. We obtained general compositional records for each site since 1907 from Harvard Forest archival materials. Stem numbers and diameters measured in 1937 were available from 0.05 -ha and 0.1 -ha (1/8 and $1 / 4$ acre) plots overlapping or adjacent to each of the current study sites. Disturbance histories for the town of Petersham and for the individual sites were compiled from a number of sources: complete records of fires, cutting, and pathogens outbreaks since 1907, along with occasional references to 19 th century logging, are available from Harvard Forest archival materials. To interpret the timing and relative impact of tropical storms, 


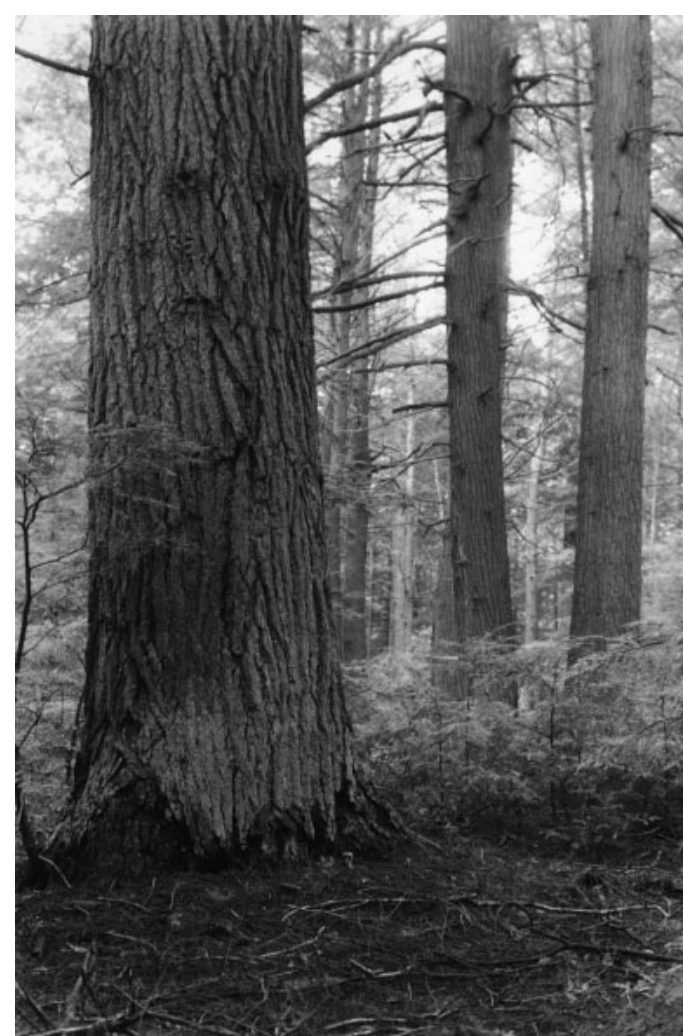

Plate 1. Photograph of the Prospect Hill II stand in the Harvard Forest, Petersham, Massachusetts, USA.

we used recent results from an effort that has reconstructed the meteorology of all hurricanes in New England since 1635 (Boose et al. 1993; E. R. Boose and D. R. Foster, unpublished manuscript). The model output from this study indicates the wind speed and inferred intensity of each storm affecting Petersham, Massachusetts, in terms of Fugita intensity values, and then compares these to actual historical records.

\section{Tree rings}

We cored all stems $>2.5 \mathrm{~cm}$ dbh in each plot at the base and measured annual growth increments to the nearest $0.01 \mathrm{~mm}$ and total age using a Velmex Unislide tree ring measuring system (Velmex Company, New York, New York, USA) and a dissecting microscope. We did not use tree cores in which the pith of the tree was not reached (59 of 490 trees) in constructing age distributions, and we note that such trees were fairly evenly distributed among stem diameter classes (the maximum percentage of trees of undetermined recruitment date in any $10 \mathrm{~cm}$ diameter class in any plot was 22\%). We cross-dated all Tsuga canadensis ring-width series with the program COFECHA (International TreeRing Data Bank, Tucson, Arizona, USA) but because cross-dating late successional trees in closed canopies is uncertain, and our study did not require extremely precise growth chronologies (Lorimer and Frelich
1989), we rarely made changes to the chronology and never altered any individual chronology by $>3 \mathrm{yr}$.

We derived detrended ring-width indices, which minimized long-term growth trends, using linear or negative exponential regressions from the program CRONOL (International Tree-Ring Data Bank, Tucson, Arizona, USA). We formed master series for two sets of crown classes at each site, dominant and codominant trees, and intermediate and suppressed trees (Kelty 1986), by averaging the total number of individual tree ring series of each class in each year. To smooth out high-frequency variability, we present 3-yr running averages of these indices derived for at least three trees. Because ring-width chronologies based on small samples may not accurately reflect growth trends at the stand level, we indicate the point at which the sampling depth reaches the more conservative level of 10 individuals for each ring-width index in Figs. 2, 3, 4, and 6 . Ring-width index values $<1$ indicate periods of reduced radial growth, and accelerated radial growth is marked by ring-width index values $>1$. Sharp growth releases followed by a gradual decline in ring width on the order of decades are interpreted here as signals of canopy disturbance (Nowacki and Abrams 1994).

To augment this subjectively determined release criterion, we calculated a modified version of the conservative release criteria determined by Lorimer and Frelich (1989) for hemlock-northern hardwood forests. The conservative criteria require that ring widths increase $>100 \%$ for at least $15 \mathrm{yr}$. We modeled the general "relatively abrupt" growth increase specified in Lorimer and Frelich (1989) as an increase of 50\% in $5 \mathrm{yr}$. The period of slower growth before release must be at least $15 \mathrm{yr}$. Canopy trees tend to have more modest growth releases following disturbance than understory trees, a trend which is apparent in the complacency of our overstory ring-width index curves to recent disturbances reflected strongly in the understory curve (i.e., Figs. 2 and 3). Because we did not follow Lorimer and Frelich (1989) in limiting our release criteria to trees of certain diameter classes, we consequently run the risk of underestimating disturbance-caused growth releases in canopy trees. We believe that this risk is minimized, however, because growth trends in our cores indicate that throughout the course of our records most of our trees were in the understory. The oldest trees in the current stands generally show repeated releases, indicating that the trees remained in the understory through several disturbance cycles, a common pattern in Tsuga canadensis growth trends (Kelty 1986). By the time these individuals reach the canopy, the basis for the release criteria analysis is weighted heavily towards younger understory trees.

Because patterns of radial growth release in our 30 $\times 30 \mathrm{~m}$ plots may be susceptible to strong signals from minor disturbances (e.g., single tree gaps), we analyzed the growth of 12-14 additional Tsuga canadensis located $30-60 \mathrm{~m}$ from the center of each plot. The timing 


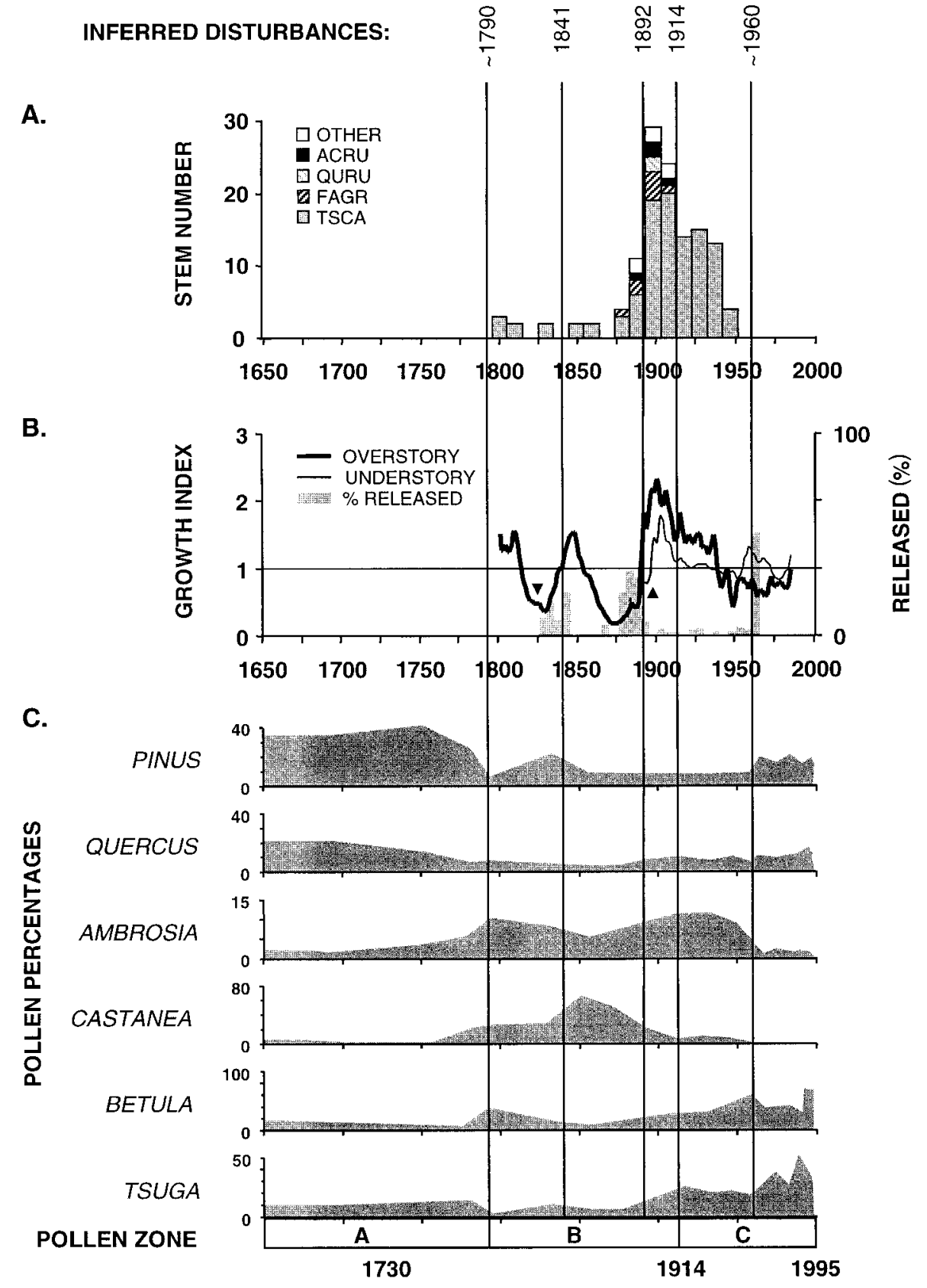

FIG. 2. Compilation of structural and compositional changes through time at Slab City IX. (A) Age class distribution for all stems aged to pith $(\mathrm{ACRU}=$ Acer rubrum, $\mathrm{QURU}=$ Quercus rubra, FAGR $=$ Fagus grandifolia , and $\mathrm{TSCA}=$ Tsuga canadensis). (B) Standardized annual radial growth of dominant and codominant hemlocks (thick line) and intermediate and suppressed hemlocks (thin line). Growth curves are based on at least three individuals. Triangles indicate the point where a sampling depth of ten individuals is reached $(\boldsymbol{\nabla}=$ overstory; $\boldsymbol{\Lambda}=$ understory $)$. The final sampling depths for these series were: overstory $=27$ individuals, understory $=86$ individuals. Gray bars indicate the percentage of all stems in each 5 -yr period showing a release by a modified version of Lorimer and Frelich's (1989) conservative criteria. (C) Pollen percentage diagram (note that the vertical scale values change among taxa). Disturbances are subjectively based on known disturbances (Table 2) and releases determined from the ring-width index.

of stem recruitment and growth release (modified criteria of Lorimer and Frelich 1989) in these trees was entirely consistent with that of the trees in the smaller plots (data not shown), thus increasing our confidence that disturbances identified from our tree ring analyses are relevant at the stand level. As the growth histories of these additional trees proved to be consistent with those of the smaller plots, they were included in the 


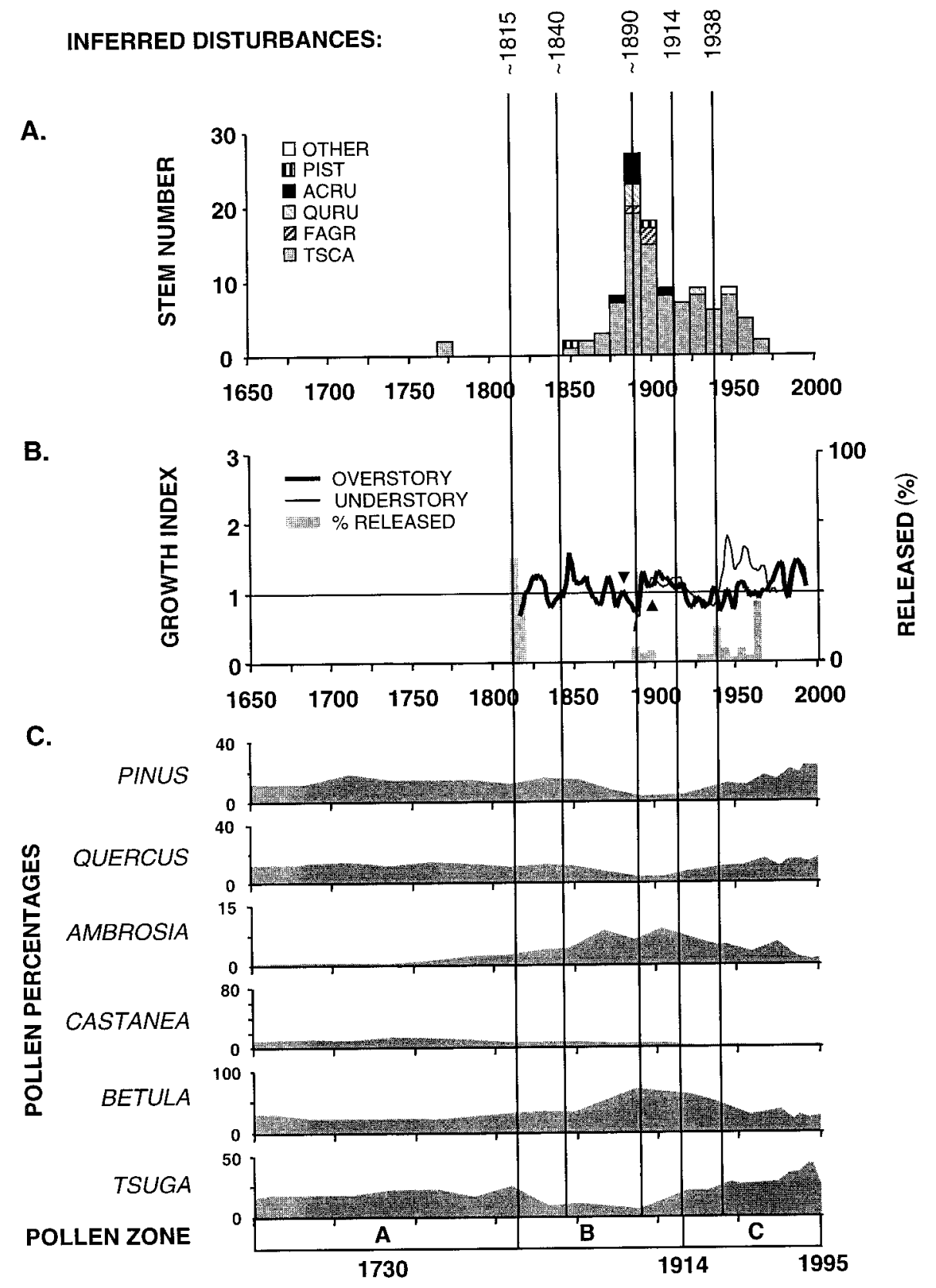

FIG. 3. Compilation of structural and compositional changes through time at Slab City X. Recruitment, radial growth and pollen percentages are shown, as in Fig. 2. In (A), ACRU $=$ Acer rubrum, PIST $=$ Pinus strobus, QURU $=$ Quercus rubra, FAGR = Fagus grandifolia, and TSCA $=$ Tsuga canadensis. In (B) final sampling depths were: overstory $=24$ individuals, understory $=71$ individuals

tree ring analyses to increase sampling depth in the early parts of the record.

\section{Stand-level pollen analysis}

We removed $30 \times 30 \mathrm{~cm}$ humus monoliths $(\mathrm{O}$ horizon) from the center of each plot. The monoliths, 20$24 \mathrm{~cm}$ in depth, were subsampled for pollen analysis, at $1-2 \mathrm{~cm}$ intervals. We processed pollen from these subsamples using the technique of Faegri and Iverson (1991) and counted at least 500 arboreal grains at each sample. We derived chronologies for the pollen records from Slab City IX and Slab City X using parabolic curves fit through three pollen stratigraphic markers: European settlement (1730), marked by an increase in the agricultural weed species Ambrosia and Poaceae associated with agricultural clearance in the region 


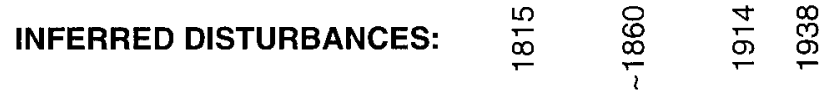

A.

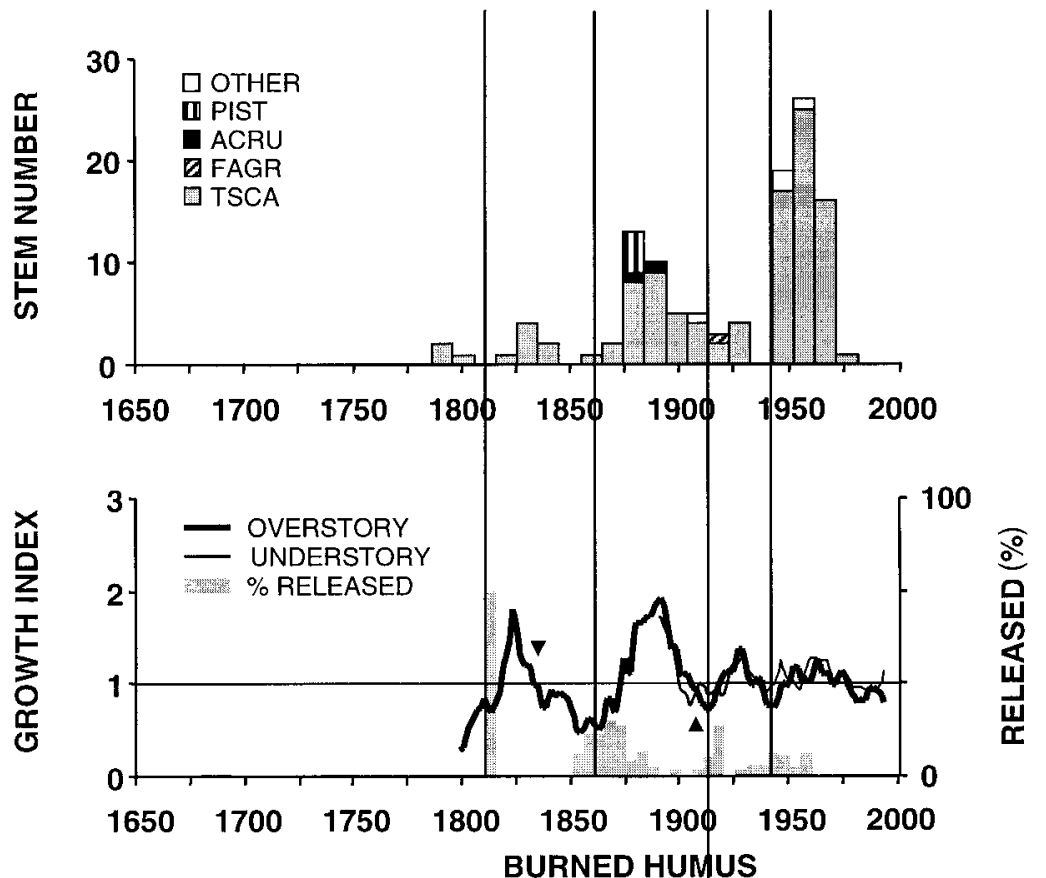

C.

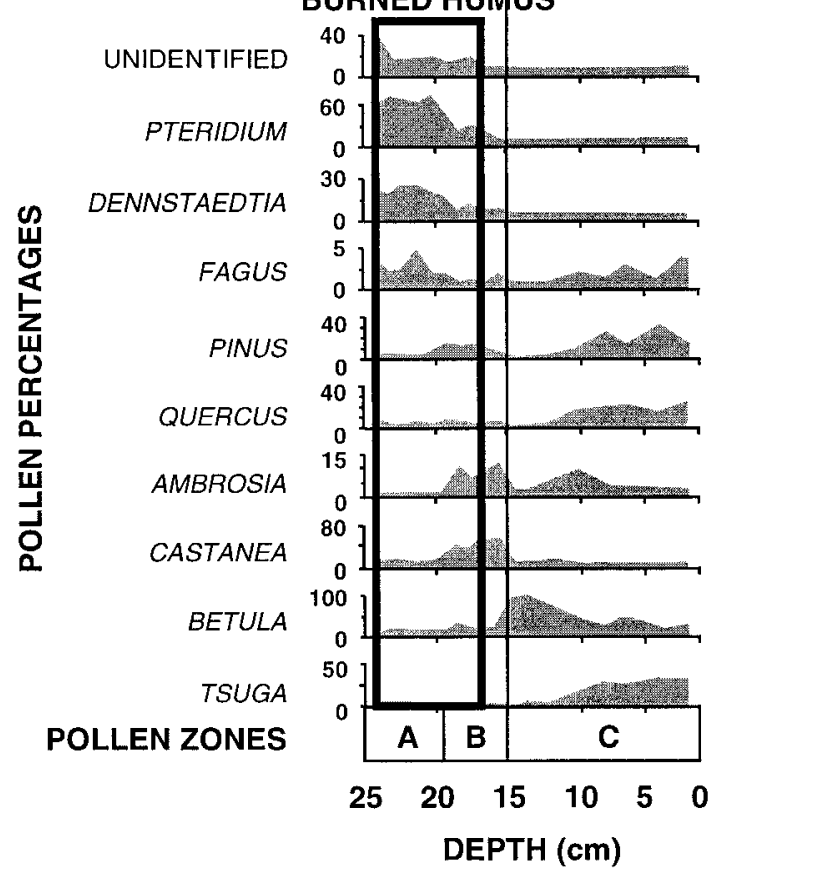

FIG. 4. Compilation of structural and compositional changes through time at Prospect Hill II. Recruitment, radial growth, and pollen percentages are shown, as in Fig. 2. In (A), PIST = Pinus strobus, ACRU $=$ Acer rubrum, FAGR $=$ Fagus grandifolia, and TSCA $=$ Tsuga canadensis. In (B) final sampling depths were: overstory $=34$ individuals, understory $=$ 76 individuals.

(Fuller et al. 1998); the chestnut blight (1914), marked by a decline in Castanea pollen; and the uppermost modern assemblage (1995). While an excellent correspondence between changes in pollen assemblages and the disturbance chronologies derived from tree ring widths implies that these chronologies may be quite accurate, we limit our discussion of stand compositional change to broad temporal periods in recognition 
of chronological uncertainty in our pollen records. The earliest pollen assemblages from the Prospect Hill II and Prospect Hill VII monoliths contain abundant pollen from agricultural weed species, indicating that they postdate European settlement. Since these sites have no European settlement horizon to provide a lower chronological marker in these records, their pollen assemblages are presented simply as a function of sample depth.

We divided pollen percentage diagrams from the four sites into three zones. Zone A contains pollen assemblages derived from presettlement forests through the first major forest compositional change following European settlement $(\sim 1730)$. Zone B represents pollen assemblages from the period of intensive land use ( 1730-1914). These assemblages contain high percentages of agricultural weed species, and are dominated by early-successional sprout hardwoods. Zone C represents pollen assemblages from the period of Tsuga canadensis dominance in these stands beginning after the decline of Castanea dentata $(\sim 1914)$. During zone $\mathrm{C}$, a decrease in the abundance of agricultural weed species is associated with regional reforestation (Fuller et al 1998). In order to compare compositional trends between sites, we ordinated arboreal pollen percentages for each site and from a similar record (Hemlock Woodlot II; Foster et al. 1992) using principal components analysis (PCA) (CANOCO version 3.11: ter Braak 1992).

In this study, the pollen accumulating in humus monoliths is considered to be largely derived from a stand-level source area. This is consistent with studies of modern pollen distribution in closed stands (Jackson and Wong 1994, Calcote 1995) and with the evidence of Foster et al. (1992) who were able to replicate compositional trends in similar humus records taken $40 \mathrm{~m}$ apart. We also note that the pollen records from Slab City IX and Slab City X are distinct, suggesting that the dominant pollen source area for the pollen records is less than the $\sim 200 \mathrm{~m}$ separating these sites. However, some regional pollen signatures do exist; for example the agricultural weed species Ambrosia is a well-dispersed pollen type and we assume that its abundance follows regional changes in open land over the postsettlement period (Fuller et al. 1998).

Abundant charcoal was found in the pollen preparations from the Prospect Hill II monolith, and is discussed below. We found no other evidence of local fire in our records.

\section{Disturbance markers}

Disturbance markers in Figs. 2, 3, 4, and 6 are based on radial growth releases, on pulses of understory recruitment, on compositional changes reflected in the pollen record, and on archival records of known disturbances at our study sites. This combination of approaches requires a subjective decision about what constitutes evidence of a disturbance, a decision which is complicated by the fact that different types and intensities of disturbance are recorded with different strengths by the various proxies. We believe that these complications are ultimately a strength of our integrated approach because differences between the proxy records often reveal important ecological attributes of a disturbance. The chestnut blight occurred soon after major timber harvests in three of our stands, for instance, so the important compositional changes marked by this disturbance were not reflected in growth releases or increased stem recruitment at these sites. At Prospect Hill II, however, structural as well as compositional changes resulted from this disturbance. Generally, we looked for correlation between proxy records as a sign of major stand disturbance. We also favored growth releases that were indicated by both an increase in standardized ring width and a high percentage of released stems.

\section{RESULTS}

\section{Modern stand characteristics and recent stand development}

At present, the sampled stands are quite similar in structure and composition (Table 1a). They are dominated by Tsuga canadensis (79-89\% of total basal area) and have very high basal areas (due primarily to large individuals) and densities (due to regenerating understory Tsuga canadensis). Although Tsuga canadensis greatly outnumber other species in all canopy layers, hardwoods, with the exception of Fagus grandifolia, occur almost exclusively in the overstory as dominant trees. The understory is composed mainly of Tsuga canadensis containing few other species. Some stands contain a few emergent Pinus strobus.

The broad developmental context of these stands can be determined by comparing their current characteristics (Table 1a) with those of 1937 (Table 1b). In 1937, all stands were dominated by Tsuga canadensis as they are today, although they generally had higher densities of various Betula species and of Acer rubrum. Despite a variety of important disturbances to the stands in the past $50 \mathrm{yr}$, this period saw a large increase in basal area in each stand and a general convergence of stem densities and basal areas between the stands. Specifically, Slab City IX and Prospect Hill VII had lower basal areas and twice the densities of the other two stands in 1937. Over the subsequent $50 \mathrm{yr}$, these denser but less massive stands doubled their basal area and maintained a fairly constant density, while Slab City $\mathrm{X}$ and Prospect Hill II increased basal area at more modest rates and doubled their densities. So, while these stands appear to have recently converged towards a similar hemlock-dominated massive structure, they are clearly not in any sort of equilibrium. The specific compositional changes associated with this trend are tied to the disturbance history of the stands, and are discussed in the following section. 
TABLE 1. Tree composition (stems $>2.5 \mathrm{~cm}$ basal diameter) of four study sites within the Slab City (SC) and Prospect Hill (PH) tracts of Harvard Forest, Petersham, Massachusetts, USA in 1995 and 1937.

\begin{tabular}{|c|c|c|c|c|c|c|c|c|}
\hline \multirow[b]{2}{*}{ Species } & \multicolumn{4}{|c|}{ Density (stems/ha) } & \multicolumn{4}{|c|}{ Basal area $\left(\mathrm{m}^{2} / \mathrm{ha}\right)$} \\
\hline & SC9 & SC10 & PH2 & PH7 & SC9 & $\mathrm{SC} 10$ & PH2 & PH7 \\
\hline \multicolumn{9}{|c|}{ a) 1995 vegetation based on $30 \times 30 \mathrm{~m}$ plots } \\
\hline Tsuga canadensis & 1133 & 900 & 1067 & 1222 & 34.1 & 36.5 & 53.1 & 39.6 \\
\hline Pinus strobus & 0 & 22 & 44 & 11 & 0 & 11 & 8.8 & 2 \\
\hline Acer rubrum & 78 & 111 & 22 & 33 & 3.5 & 7.6 & 1.4 & 2.4 \\
\hline Quercus rubra & 22 & 22 & 0 & 55 & 3.4 & 3.4 & 0 & 5.5 \\
\hline Fagus grandifolia & 89 & 56 & 11 & 11 & 6.6 & 1.1 & 0 & 0.2 \\
\hline Betula lenta & 78 & 0 & 44 & 33 & 4.6 & 0 & 0.3 & 1.5 \\
\hline Betula papyrifera & 11 & 0 & 0 & 11 & 0.9 & 0 & 0 & 0.2 \\
\hline Betula alleghaniensis & 0 & 0 & 0 & 11 & 0 & 0 & 0 & 0.2 \\
\hline Fraxinus americana & 11 & 33 & 0 & 0 & 0.5 & 0.7 & 0 & 0 \\
\hline Total & 1411 & 1111 & 1188 & 1387 & 53 & 59.5 & 63.6 & 51.5 \\
\hline
\end{tabular}

b) 1937 vegetation based on $500-\mathrm{m}^{2}$ (1/8 acre) plots adjacent to 1995 study sites.

\begin{tabular}{lrrrrllll} 
Tsuga canadensis & 622 & 415 & 395 & 682 & 17 & 32.7 & 40.2 & 11.5 \\
Pinus strobus & 0 & 0 & 10 & 69 & 0 & 0 & 0.2 & 1.7 \\
Acer rubrum & 198 & 0 & 138 & 287 & 3.2 & 0 & 1.1 & 4.7 \\
Quercus rubra & 10 & 0 & 0 & 69 & 0.2 & 0 & 0 & 2 \\
Fagus grandifolia & 30 & 0 & 0 & 109 & 0.9 & 0 & 0 & 1.4 \\
Betula lenta & 277 & 79 & 20 & 267 & 2.9 & 6.2 & 0.3 & 4.5 \\
Betula papyrifera & 69 & 0 & 20 & 10 & 2.1 & 0 & 0.7 & 0.2 \\
Betula alleghaniensis & 99 & 178 & 0 & 0 & 1 & 5.3 & 0 & 0 \\
Fraxinus americana & 0 & 0 & 0 & 10 & 0 & 0 & 0 & 0.2 \\
Populus sp. & 20 & 0 & 0 & 0 & 0.4 & 0 & 0 & 0 \\
Ulmus americana & 0 & 20 & 0 & 0 & 0 & 2.9 & 0 & 0 \\
Acer saccharum & 0 & 20 & 0 & 0 & 0 & 2 & 0 & 0 \\
Picea rubens & 0 & 0 & 10 & 0 & 0 & 0 & 0 & 0 \\
Total & 1205 & 494 & 583 & 1492 & 26.3 & 38.9 & 42.5 & 26 \\
\hline
\end{tabular}

Pollen, tree ring, and historical data

Slab City IX.-Pollen assemblages in zone A (Fig. 2C) represent forest conditions from presettlement times (before 1730) to the first major compositional change after European settlement. Agricultural weed species such as Ambrosia, interpreted here as indicators of regional deforestation, have very low percentages during the presettlement period and increase only slightly in zone A. Quercus and haploxylon-type Pinus are the most common pollen types in the presettlement assemblages, presumably representing Quercus rubra and Pinus strobus. Early successional to midsuccessional Castanea dentata and Betula are present though not abundant, as is the late-successional Tsuga canadensis.

The start of the period of intensive human disturbance at the site (Zone B), is signaled by a rise in Castanea dentata and Betula along with a further increase in Ambrosia pollen (Fig. 2C). Uncertainties in the pollen chronology prohibit assigning a precise date to this event but it may coincide with the recruitment of the oldest trees in the stand (Fig. 2A), and a period of above average radial growth (Fig. 2B) in the early 1800s. Castanea dentata dominates pollen percentages early in Zone B along with a pulse of Betula. Spurr (1950) suggests that the site was heavily logged in 1841 (Table 2), an event which seems to have precipitated a large growth release (Fig. 2B), and possibly compositional shifts indicated by peaks in the pollen of
Pinus strobus and Tsuga canadensis, and further increases in Castanea. The last major anthropogenic disturbance to the stand was a logging event in 1892 (Table 2), marked by a large growth release (Fig. 2B), and the establishment of most of the site's hardwoods, and a pulse of Tsuga canadensis (Fig. 2A).

The transition to zone $\mathrm{C}$ of the pollen diagram, and the emergence of the modern Tsuga canadensis-dominated assemblage, is marked by the elimination of Castanea dentata from the forest canopy starting in 1912 (Table 2). At Slab City IX, the chestnut blight had a dramatic compositional impact, as the dominant Castanea dentata was replaced by Tsuga canadensis, Betula, and, to a lesser extent, Quercus. Following closely behind the logging event of 1892 , however, the blight did not have a marked effect on the growth of existing trees (Fig. 2B), although it may have prolonged the period of elevated growth and recruitment rates following this earlier disturbance (Fig. 2A, B). During the second half of zone C, decreasing Ambrosia pollen percentages signal the return of the landscape to more fully forested conditions. Tree pollen percentages at the site show continuing changes, including further increases in Tsuga canadensis, a minor increase in Pinus strobus, and a recent spike of Betula pollen (Fig. 2C). While there are no archival records of major disturbances at this site since the chestnut blight (Table 2), understory Tsuga canadensis experienced aboveaverage growth during the last $50 \mathrm{yr}$ and major growth 
TABle 2. Disturbance history of Petersham, Massachusetts, and four study sites within Slab City (SC) and Prospect Hill (PH) tracts of Harvard Forest, based on records at the Harvard Forest Archives.

\begin{tabular}{|c|c|c|c|}
\hline Year & Event & Intensity $\dagger$ & Stand \\
\hline 1635 & Hurricane & $1.5 \mathrm{~F}$ & \\
\hline 1675 & Hurricane & $1.1 \mathrm{~F}$ & \\
\hline 1727 & Hurricane & $1.0 \mathrm{~F}$ & \\
\hline 1730 & $\begin{array}{l}\text { Settlement of } \\
\text { Petersham }\end{array}$ & & \\
\hline 1761 & Hurricane & $1.0 \mathrm{~F}$ & \\
\hline 1788 & Hurricane & $1.3 \mathrm{~F}$ & \\
\hline 1790 & Chestnut cutting & & PH2 \\
\hline 1804 & Hurricane & $0.8 \mathrm{~F}$ & \\
\hline 1815 & Hurricane & $1.9 \mathrm{~F}$ & $\mathrm{PH} 2, \mathrm{SC} 10 ?$ \\
\hline 1821 & Hurricane & $1.6 \mathrm{~F}$ & \\
\hline 1841 & Logging & & SC9, SC10? \\
\hline 1841 & Hurricane & $1.0 \mathrm{~F}$ & \\
\hline 1869 & Hurricane & $1.0 \mathrm{~F}$ & \\
\hline $1870-1878$ & Chestnut cutting & & PH2, PH7? \\
\hline 1892 & Logging & & SC9, SC10? \\
\hline $1912-1914$ & Chestnut blight & & \\
\hline 1924 & Hurricane & $1.1 \mathrm{~F}$ & \\
\hline 1938 & Hurricane & $2.3 \mathrm{~F}$ & $\begin{array}{c}\mathrm{PH} 2, \mathrm{PH} 7, \\
\text { SC10 }\end{array}$ \\
\hline 1940 & Salvage cutting & & PH2 \\
\hline 1944 & Hurricane & $0.5 \mathrm{~F}$ & \\
\hline 1945 & Gypsy moth & & \\
\hline 1949 & Logging & & PH7 \\
\hline 1949 & Chestnut salvage & & PH2 \\
\hline 1954 & Hurricane & $1.0 \mathrm{~F}$ & \\
\hline 1960 & Hurricane & $0.7 \mathrm{~F}$ & \\
\hline 1963 & Hemlock thinning & & PH7 \\
\hline 1982 & Gypsy moth & & \\
\hline 1985 & Hurricane & $0.9 \mathrm{~F}$ & \\
\hline 1991 & Hurricane & $0.5 \mathrm{~F}$ & \\
\hline
\end{tabular}

Note: Estimates of hurricane impacts are based on the reconstruction of all tropical storms that have had an impact on the New England landscape since 1635 (Boose et al. 1993 E.R. Boose and D.R. Foster, unpublished manuscript).

$\dagger$ Hurricane intensities are indicated in the Fugita scale, with categories for forests on exposed sites: F1 (117-180 km/ $\mathrm{h}$; isolated groups of trees blown down), F2 (181-254 km/h; extensive blowdowns), and F3 (255-331 km/h; most trees blown down).

releases in the 1960s. This growth trend is consistent with the doubling of stand basal area since 1937 (Table 1), during which time the stand increased its percentage of Tsuga canadensis considerably, at the expense of hardwood species such as Acer rubrum, Betula lenta, and Betula alleghaniensis.

Slab City X.-Presettlement pollen assemblages (Zone A) include both early successional to midsuccessional taxa, such as Betula, Quercus, and Pinus strobus, and the late successional species Tsuga canadensis and Fagus grandifolia (Fig. 3C). The end of this presettlement assemblage is marked by a drop in Tsuga canadensis pollen abundance around 1815 (Fig. 3C), indicating a period of intensive local disturbance corresponding to a distinct growth release among our oldest trees (Fig. 3B). The year 1815 is also the date of the second most damaging hurricane to affect Petersham in New England's recorded history (Table 2). A subsequent major compositional change occurs later, when Pinus strobus, Castanea dentata, and Quercus percentages simultaneously drop and are replaced by Betula. The timing and magnitude of this Betula increase suggests that it represents a response to human disturbance, and a series of small growth releases throughout the 19th century may correspond to allogenic disturbances (Fig. 3B). Although Slab City X currently contains no Betula species, the high basal areas of Betula alleghaniensis and Betula lenta at the site in 1937 (Table 1b) may indicate that these species were more important in the Betula-dominated late 1800s. Most of the stand's current stems, and almost all its hardwood stems, were recruited at the time of a moderate growth release around 1890 (Fig. 3A, B). It is possible that this disturbance is the same 1892 cutting event responsible for the large cohort of trees at Slab City IX (Table 2), or it may be an unrelated event.

The early 20th century marks the last major compositional shift at the site and the beginning of Zone $\mathrm{C}$, as Castanea dentata pollen percentages, which decline throughout the postsettlement period, drop to zero with the chestnut blight (Fig. 3C). Betula percentages decline rapidly and major increases occur in Pinus strobus, Quercus, and especially Tsuga canadensis. As at Slab City IX, the decline in Ambrosia reflects the regional decrease of open agricultural land. Major 20th century disturbances had mixed effects on the composition of the stand: the chestnut blight is not strongly reflected in tree recruitment or growth releases, perhaps because Castanea dentata had low abundances before the blight (Fig. 3C). Increased growth of understory Tsuga canadensis in the 1940 s and 1950s (Fig. 3B) may represent a response to the 1938 hurricane that severely damaged this stand (Table 2). Slab City X is unusual among our study sites in having doubled Tsuga canadensis density over the past $50 \mathrm{yr}$, but gained relatively little basal area for this species (Table 1). Since 1937 most of the stand's increase in basal area has come from Pinus strobus, Acer rubrum, and Quercus rubra, while Betula species, formerly the dominant hardwood taxa in the stand, were eliminated from the stand.

Prospect Hill II.-A fire seems to have obscured the early pollen record from this site. Below $16 \mathrm{~cm}$ in the humus monolith, pollen are poorly preserved and charcoal fragments are abundant (Fig. 4C). However, the absence of fire scars on trees or widespread soil charcoal suggests that the burned humus is the result of a very local or minor understory burn rather than a major fire. Pollen percentages from this burned humus are not reliable due to large percentages of unidentifiable pollen, but the general compositional trends noted here are stratigraphically sensible, and generally consistent with adjacent humus pollen records from the same stand (Fig. 5: adapted from Foster et al. 1992). We note that pollen percentages from the Prospect Hill II monolith are consistent across the boundary of the burned humus layer (Fig 4C: $17 \mathrm{~cm}$ ) indicating that they are not artifacts of poor pollen preservation. Pollen Zone 
FIG. 5. Pollen percentages from Hemlock Woodlot II (modified from Fig. 5 of Foster et al. 1992). Note that the vertical scale values change among taxa.

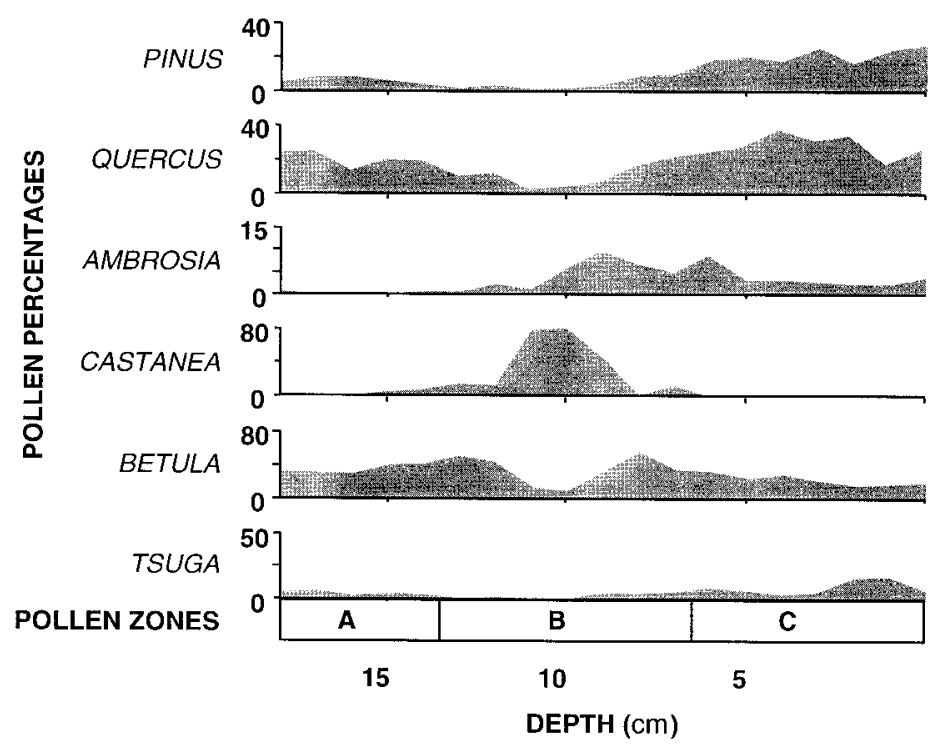

pulse of Betula, followed by the establishment of the current pollen assemblage of Tsuga canadensis, Pinus strobus, and Quercus (Fig. 4C). Foresters at Harvard Forest once again referred to this stand as "old-growth hemlock" in 1937. At the time, it had a higher basal area than any of the other sites investigated here and it had a lower proportion of hardwoods than the other stands (Table $1 \mathrm{~b}$ ). In response to moderate damage from the 1938 hurricane and subsequent salvage operation (Table 2), an understory growth increase was accompanied by a wave of understory Tsuga canadensis recruitment (Fig. 4A, B). Between 1937 and 1995, most of the Acer rubrum stems died and the basal area of Tsuga canadensis and Pinus strobus increased considerably (Table 1).

Prospect Hill VII.-The oldest pollen assemblages from this site postdate European settlement, as indicated by abundant Ambrosia pollen and high percentages of Castanea and Pinus strobus (Fig. 6C), similar to Zone B from Prospect Hill II and Slab City IX. The oldest trees in the stand recruited in the 1860s and 1870 s, with high growth rates suggesting response to disturbance (Fig. 6A, B). In the early 1890s, another growth release coincides with the recruitment of almost all of the stand's current hardwood component and most of the Tsuga canadensis. Archival records depict this as a "good hardwood stand" in 1908 (Harvard Forest, unpublished manuscript).

The chestnut blight ended the period of Castanea dentata dominance and signals the start of pollen Zone C (Fig. 6C). While Tsuga canadensis responded to this disturbance with increased growth (Fig. 6B), the blight apparently did not result in elevated recruitment (Fig. 6A). However, the pollen record (Fig. 6C) and the 1937 stand analysis (Table 1b), suggest that Betula lenta, Fagus grandifolia, and Acer rubrum may have been abundant in the decades following the blight, and then
The decline in Castanea pollen at $14 \mathrm{~cm}$ signals the start of Zone $\mathrm{C}$ and the chestnut blight, which resulted in a moderate growth release (Fig. 4B), and a temporary 


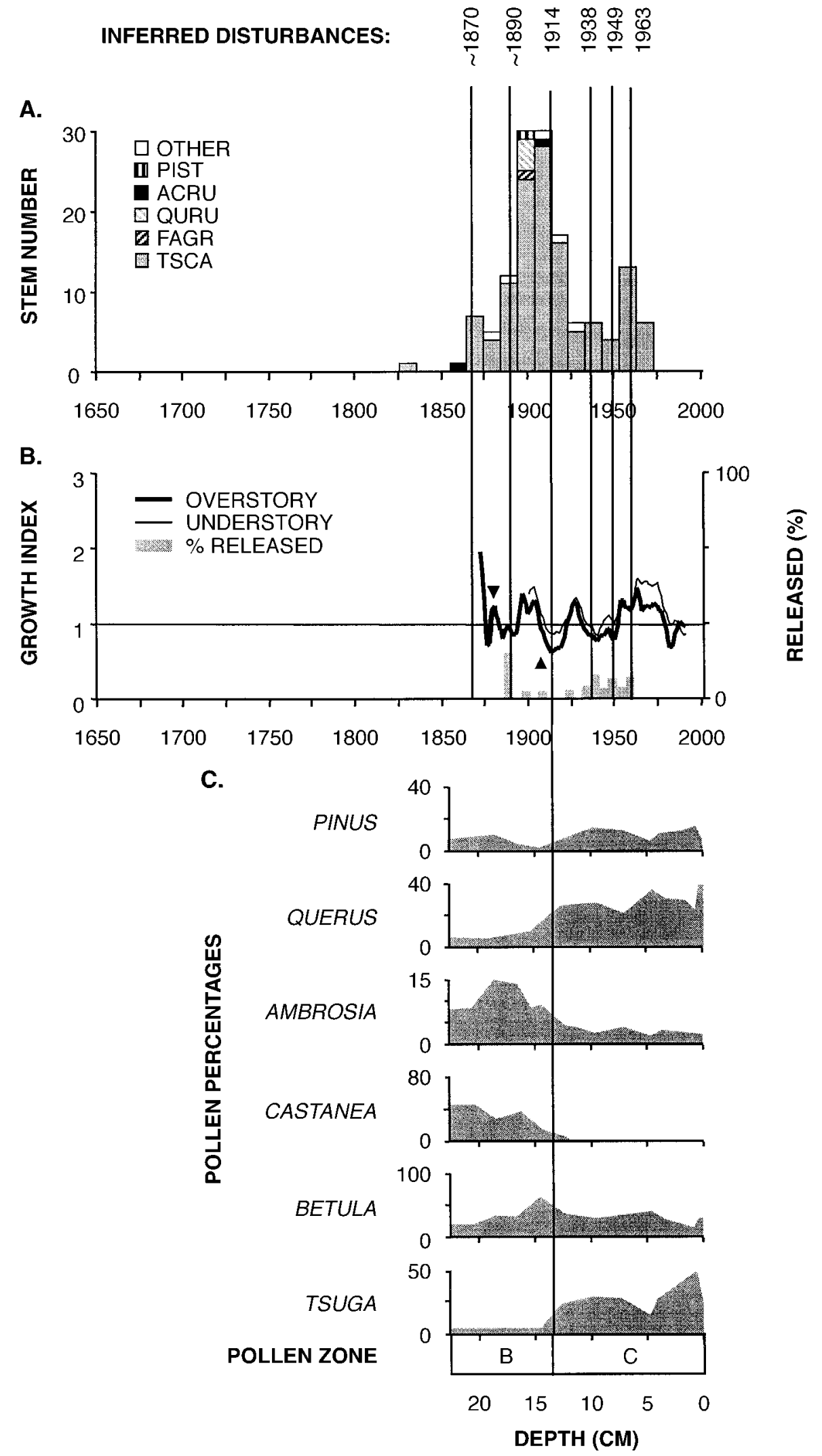


subsequently died. In addition to these hardwood species, Prospect Hill VII was dominated by Tsuga canadensis in 1937 (Table 1b) and also had "a lot of salvageable [dead] chestnut" (Harvard Forest, unpublished manuscript). The stand underwent a period of low growth and recruitment in the early 20th century despite damage from the 1938 hurricane. It was subsequently released in 1949 when hardwoods were preferentially cut. The effectiveness of this silvicultural treatment is apparent in the switch from Betula to Tsuga canadensis dominance in the pollen diagram (Fig. 6C; $\sim 5 \mathrm{~cm}$ ), and increases in Tsuga canadensis growth and recruitment (Fig. 6A, B). The stand was thinned a second time in 1963, resulting in a moderate understory growth release.

Comparison of compositional trends.-A PCA ordination of pollen assemblages from our four study sites, plus a comparable site near the Prospect Hill II site (Hemlock Woodlot II in Foster et al. 1992), allows a comparison of broad compositional trends over the past $300 \mathrm{yr}$ (Fig. 7). Presettlement pollen assemblages (Pollen Zone A in Fig. 7) vary in composition, ranging in ordination space from northern hardwood assemblages with Fagus grandifolia, Betula, and Acer saccharum components (Hemlock Woodlot II) to Quercus rubra-Pinus strobus assemblages (Slab City IX). With the onset of European land use (pollen Zone B), the sites diverge towards assemblages dominated by Castanea dentata or, in the case of Slab City X, Betula. Zone $\mathrm{B}$ assemblages are marked by rapid change, often moving from Castanea dentata dominance through transitional Betula-dominated assemblages after the chestnut blight and finally converging at the Tsuga canadensis-dominated assemblage characteristic of Zone C. In the 20th century, the trajectories of the five compositional histories become indistinguishable (Fig. 7), as recent stand development patterns have made the stands even more similar (Table 1). It is clear that the current composition of our sites is not analogous to presettlement forest composition and that there has been no shift towards presettlement composition in the $100 \mathrm{yr}$ since the stands received their last strong anthropogenic disturbance (Fig. 7).

\section{Discussion}

\section{History of four primary hemlock stands}

This study provides an unusually detailed analysis of the long-term pace and magnitude of vegetation change. The novel reconstructive approach we employed allowed us to link the long-term compositional history of each stand, derived from the pollen records, with the suite of disturbances and environmental stresses that produced it, based on tree ring and historical data. In general, we found that four apparently stable stands had experienced important disturbances every few decades over the past $300 \mathrm{yr}$ (Figs. 2, 3, 4, and 6) and major compositional change on the order of every century (Fig. 7). We summarize the development of these forests, highlighting new ecological insights gained from using an integrated reconstructive approach.

The structure, composition, and dynamics of presettlement forests in southern New England has largely been obscured by centuries of intensive land use, although forest historians (Whitney 1994, Foster et al. 1998) and paleoecologists (Davis 1958, Fuller et al. 1998) suggest that, regionally, they were characterized by late-successional assemblages of Fagus grandifolia and Tsuga canadensis. Our results show that, at a more local scale, a diverse mixture of presettlement forests, often containing abundant early successional and midsuccessional species, coexisted on the landscape. Immediately preceding European settlement (pollen zone A), the Slab City IX forest, located on a well drained hill slope, was dominated by midsuccessional species such as Pinus strobus and Quercus rubra (Fig. 2), whereas forests at Slab City X, located in a moist depression less than $200 \mathrm{~m}$ distant, included higher percentages of Castanea dentata, Betula, and the late-successional species Tsuga canadensis (Fig. 3). Presettlement forests near our Prospect Hill II site, a moist protected area, were interpreted as northern hardwoods-Tsuga canadensis/Pinus strobus assemblages (Fig. 5 in Foster et al. 1992), and longer records indicate very low rates of presettlement disturbance in the area (Foster and Zebryk 1993). The sites occur in a variety of topographic settings, but their soils are not notably different, and it is unclear whether underlying site differences can account for the compositional differences we found.

In addition to differences among site conditions, it is natural to consider what sort of disturbance regimes could result in this disparate assembly of stands. Nowacki and Abrams (1994) and Foster (1988) documented periodic disturbances in the presettlement era in widely different parts of the northeast which they attributed to fires, windstorms, and pathogen outbreaks. Presettlement Native American activity in the Central Upland region was much lower than in other parts of Massachusetts, such as coastal areas and the Connecticut River Valley (Bragdon 1996, Fuller et al. 1998; M. Mullholland, personal communication). Popula-

FIG. 6. Compilation of structural and compositional changes through time at Prospect Hill VII. Recruitment, radial growth, and pollen percentages are shown, as in Fig. 2. In (A), PIST = Pinus strobus, ACRU $=$ Acer rubrum, QURU $=$ Quercus rubra, FAGR = Fagus grandifolia, and TSCA $=$ Tsuga canadensis. In (B), final sampling depths were: overstory $=70$ individuals, understory $=57$ individuals. 

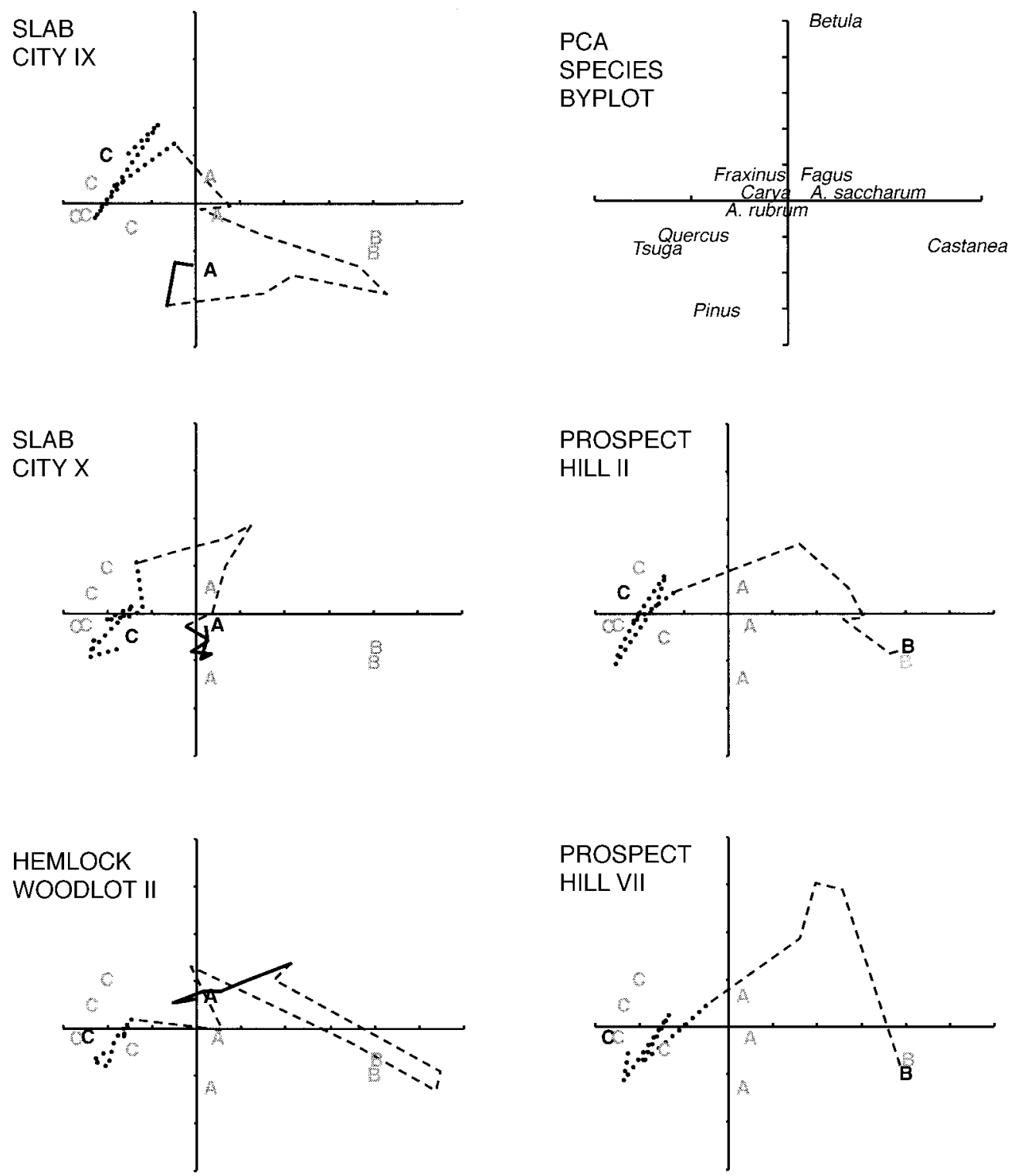

FIG. 7. First two axes of a PCA ordination of arboreal pollen assemblages from each site, plus the Hemlock Woodlot II site from Foster et al. (1992), and the species byplot for this ordination. Solid lines indicate stand composition before European land use (Pollen Zone A), dashed lines indicate the period of intensive land use (Pollen Zone B), and dotted lines indicate 20th-century stand compositions (Pollen Zone C). The beginning and ending points for each site are shown in gray to facilitate cross-referencing between sites.

tions were small, fire frequencies were generally quite low, and there is little evidence for permanent villages or extensive clearing for agriculture. Unfortunately, no trees in the stands we analyzed originated in presettlement times, so we can not link our information on stand compositions at this time to the disturbance regimes that produced them. Overall, our data suggest a matrix of disturbance and topographically determined community types in the presettlement landscape, but more ecological and anthropological work needs to be done to characterize the forests of the pre-European era and their physical and cultural contexts.
The enormous changes that agricultural life brought to the New England landscape in the 18th and 19th centuries affected even the uncommon places that remained forested. Early 20th century foresters believed that stands like Slab City X approximated "a composition similar to that of the original forests" (Harvard Forest, unpublished manuscript) and designed a silviculture to mimic the "natural" structures and processes they saw there. It is only through historical studies like ours that differences between presettlement forests and modern old-looking forests become apparent. At our sites, pollen, tree ring, and historical evidence shows 
that repeated major disturbances during this period created highly dynamic assemblages of early-successional species.

Understanding the developmental processes underlying specific compositional shifts is more difficult to do. For instance, at Slab City IX, Prospect Hill II, and Prospect Hill VII, Castanea dentata was favored by 19th century disturbance (Figs. 2, 4, and 6) but an equally intense disturbance history resulted in Betula dominance at Slab City X (Fig. 3). Recognizing such contrasts in the empirical record can help refine our characterization of the basic ecological trade-offs underlying successional dynamics in northeastern forests. Dominance of disturbed stands by Betula alleghaniensis is a prediction of the stand simulation model SORTIE (Deutschman et al. 1997). The generality of this prediction is challenged, however, by our observation that subtle differences in the timing and magnitude of disturbance may mean the difference between successional dominance of a small-seeded gap colonizer (Betula alleghaniensis) and a heavy-seeded sprouter (Castanea dentata).

Just as dramatic as the disturbance-mediated rise of early-successional species in the period dominated by anthropogenic disturbance (Zone B), was their disturbance-mediated decline at the end of this period. It is clear from historical documents and radial growth chronologies that the logging and windstorms that created stands of Castanea dentata and Betula, also released shade tolerant Tsuga canadensis into the canopy. As early as 1908, stands which had experienced several major disturbances exhibited "old-growth" structure and composition (Harvard Forest, unpublished manuscript). Each of the stands investigated here moved from early-successional hardwoods to Tsuga canadensis as a result of windstorms, pathogen outbreaks and logging rather than through gradual autogenic processes, an observation that echoes the recent challenge of Abrams and Orwig (1996) to the conception of this species as being a characteristically late-successional climax species. Other reconstructive studies have documented the emergence of late-successional compositions through the effect of canopy-removing disturbance (Oliver and Stephens 1977, Kelty 1986, Abrams and Scott 1989, Abrams and Nowacki 1992) suggesting that complicated and counterintuitive successional dynamics may be fairly common in the Northeast.

Since 1937, the four stands have become more massive and more dominated by Tsuga canadensis (Table 1 ), and show no sign of returning to their presettlement composition (Fig. 7). Stand development during this period was influenced by a few major disturbances such as the 1938 hurricane and the silvicultural thinning at Prospect Hill VII (Table 2), but increased understory growth, and Tsuga canadensis recruitment during the last $50 \mathrm{yr}$ may also be a product of additional light resources becoming available as the stands enter the understory reinitiation stage 50-100 yr after distur- bances in the 1890s (Oliver and Larson 1996). Current stand developmental trends, therefore, indicate that the stands will continue their trend towards dominance by massive old Tsuga canadensis, an unusual assemblage in a post-agricultural landscape in which Tsuga canadensis is not being strongly reestablished (Fuller et al. 1998). An important lesson of this study, however, is the role of unpredictable historical events in longterm stand history. For example, stands such as these are currently threatened by logging pressures, and the introduced hemlock wooly adelgid (Adelges tsugae) (Orwig and Foster 1998). Indeed, preemptive logging of Tsuga canadensis in anticipation of adelgid damage is already occurring in the region (USDA 1996).

\section{Lessons from long-term forest history}

Ecologists have recently made great advances in understanding the mechanisms behind forest response to disturbance (Clark 1996, Pacala et al. 1996, Fahey et al. 1998). Long-term empirical studies, such as this one, can contribute to this understanding in two ways. First, by outlining general trends in forest development, such studies indicate which dynamics are likely to have important long-term consequences, and constrain speculative ideas about the past (Davis et al. 1998, Fuller et al. 1998). In this study, the ecological forces that produced the characteristic structure and composition of old-growth forests were anthropogenic and the pacing of change in the forest was set by long-term trends in the cultural history of southern New England, rather than long-term processes of autogenic succession. We also found that several Tsuga canadensis stands characterized in the 20th century as "old-growth," and "representative of the original forest," were dominated by early successional and midsuccessional species in presettlement times.

Second, long-term empirical studies can provide examples of specific compositional transitions useful for verifying the predictions of forest successional models. Dendroecological studies can provide information on the timing and magnitude of disturbances that result in specific modern assemblages (Hibbs 1982, Kelty 1986, Abrams and Scott 1989). By combining tree ring chronologies with stand-level pollen stratigraphies, this study provides detailed information on compositional trends before such disturbances. Subtle differences between disturbance histories at our sites created stands with divergent 19 th century hardwood compositions, but these differences were hidden by the institution of novel 20th century disturbance regimes. Without the integrated approach employed here, the diverse early histories of these stands would be overshadowed by their recent compositional convergence.

Finally, documenting long-term change in forest stands can have important implications for conservation efforts. Studies of the developmental history of eastern old-growth forests have found a wide variety of stand dynamics, ranging from stands with remark- 
ably little disturbance (Davis et al. 1998), to stands dominated by periodic natural disturbances (Henry and Swan 1974, Abrams et al. 1995, Abrams and Orwig 1996), to stands with distinct anthropogenic influences (Bormann and Buell 1964, Patterson and Foster 1990, Nowacki and Abrams 1994). We found that, rather than "islands in time" (Cook 1997), our sites are intimately linked to the modern cultural landscape. It might be argued that, in identifying anthropogenic influences in these stands, we have excluded them from the category "old-growth" (Dunwiddie and Leverett 1996). It would be difficult, however, to make a meaningful ecological distinction between late-successional stands with anthropogenic ties, like our study sites, the Alan Seeger Natural Area of Pennsylvania (Nowacki and Abrams 1994), and the Cathedral Pines of Cornwall, Connecticut (Patterson and Foster 1990), and oldgrowth stands with more natural origins like the Pisgah forest of New Hampshire (Foster 1988). More importantly, in the eastern United States, where the vast majority of forests have direct anthropogenic origins, and all forests are subject to such indirect human influences as atmospheric deposition of nutrients (Likens et al. 1996), and changing herbivore populations (Whitney 1984), the long-term dynamics described in this study, dominated by anthropogenic disturbance and environmental change, are more likely to represent the character of forest change in the future than any model based on a static environment.

\section{ACKNOWLEDGMENTS}

We thank Elaine Doughty, Ben Slater, and Mike Binford for providing assistance on this project. Marc Abrams, Mary Campbell, Susan Clayden, Janice Fuller, Greg Nowacki, Dave Orwig, anonymous reviewers, and the laboratory groups of Jim Clark and David Foster provided critical reviews of the manuscript. Mary Campbell also provided much needed field assistance. This project was supported by the A. W. Mellon Foundation and the National Science Foundation (DEB 94 08056 and BIO 94-11975), and is a product of the Harvard Forest Long Term Ecological Research Program.

\section{Literature Cited}

Abrams, M. D. and G. J. Nowacki. 1992. Historical variation in fire, oak recruitment, and post-logging accelerated succession in central Pennsylvania. Bulletin of the Torrey Botanical Club 119:19-28.

Abrams, M. D. and D. A. Orwig. 1996. A 300-year history of disturbance and canopy recruitment for co-occurring white pine and hemlock on the Allegheny Plateau, USA. Journal of Ecology 84:353-363.

Abrams, M. D., D. A. Orwig, and T. E. Demeo. 1995. Dendroecological analysis of successional dynamics for a presettlement-origin white-pine-mixed-oak forest in the southern Appalachians, USA. Journal of Ecology 83:123133.

Abrams, M. D. and M. L. Scott. 1989. Disturbance-mediated accelerated succession in two Michigan forest types. Forest Science 35:42-49.

Boose, E. R., D. R. Foster, and M. Fluet. 1993. Hurricane impacts to tropical and temperate forest landscapes. Ecological Monographs 64:369-400.

Bormann, F. H. and M. F. Buell. 1964. Old-age stand of hemlock-northern hardwood forest in central Vermont. Bulletin of the Torrey Botanical Club. 91:451-465.

Bragdon, K. J. 1996. Native people of southern New England 1500-1650. University of Oklahoma Press, Norman, Oklahoma, USA.

Brake, R. W. and H. A. Post. 1941. Natural restocking following hurricane damaged 'old-field' white pine areas in north central Massachusetts. MFS thesis, Harvard University, Cambridge, Massachusetts, USA.

Calcote, R. R. 1995. Pollen source area and pollen productivity: Evidence from forest hollows. Journal of Ecology 83:591-602.

Clark, J. S. 1996. Testing disturbance theory with long-term data: Alternative life-history solutions to the distribution of events. American Naturalist 148:976-996.

Cook, A. E. 1997. The Cook Forest: An Island in Time. Falcon Press, Helena, Montana, USA.

Davis, M. B. 1958. Three pollen diagrams from Central Massachusetts. American Journal of Science 256:540-570.

Davis, M. B., R. R. Calcote, S. Sugita, and H. Takahara. 1998. Patchy invasion and the origin of a hemlock-hardwoods forest mosaic. Ecology 79:2641-2659.

Davis, M. B., S. Sugita, R. R. Calcote, J. Ferrari, and L. E. Frelich. 1994. Historical development of alternate communities in a hemlock-hardwood forest in northern Michigan, USA. in P. J. Edwards, R. May, and N. R. Webb, editors. Large Scale Ecology and Conservation Biology. Blackwell Scientific Publishers, Oxford, UK.

Deutschman, D. H., S. A. Levin, C. Devine, and L. A. Buttel. 1997. Scaling from trees to forests: Analysis of a complex simulation model. Science 277:1623.

Dunwiddie, P. W., D. R. Foster, D. Leopold, and R. Leverett. 1996. Old-growth forests in southern New England, New York, and Pennsylvania. in Mary B. Davis, editor. Northeastern old-growth forests. Island Press., Washington, D.C. USA.

Dunwiddie, P. W. and R. T. Leverett. 1996. Survey of oldgrowth forests in Massachusetts. Rhodora 98(896):419444.

Faegri, K. and J. Iverson. 1991. Textbook of pollen analysis. Blackwell Scientific Publications, Oxford, UK.

Fahey, T. J., J. J. Battles, and G. F. Wilson. 1998. Responses of early successional northern hardwood forests to changes in nutrient availability. Ecological Monographs 68:183212.

Foster, D. R. 1988. Disturbance history, community organization and vegetation dynamics of the old-growth Pisgah Forest, south-western New Hampshire, U.S.A. Journal of Ecology 76:105-134.

Foster, D. R. 1992. Land-use history (1730-1990) and vegetation dynamics in central New England, USA. Journal of Ecology 80:753-772.

Foster, D. R. 1995. Land-use history and four hundred years of vegetation change in New England. Pages 255-319 in Turner, B. L., A. Gomez Sal, F. Gonzalez Bernaldez, and F. di Castri, editors. Global land-use change: a perspective from the Columbian encounter. Consejo Superior de Investigaciones Cientificas, Madrid, Spain.

Foster, D. R. and E. R. Boose. 1992. Patterns of forest damage resulting from catastrophic wind in central New England, USA. Journal of Ecology 80:79-98.

Foster, D. R., G. Motzkin, and B. Slater. 1998. Land-use history as long-term broad-scale disturbance: Regional forest dynamics in central New England. Ecosystems 1:96119.

Foster, D. R., D. A. Orwig, and J. S. McLachlan. 1996. Ecological and conservation insights from reconstructive studies of temperate old-growth forests. Trends in Ecology and Evolution 11:419-424.

Foster, D. R. and T. M. Zebryk 1993. Long-term vegetation 
dynamics and disturbance history of a Tsuga-dominated forest in New England. Ecology 74:982-998.

Foster, D. R., T. M. Zebryk, P. Schoonmaker, and A. Lezberg. 1992. Post-settlement history of human land-use and vegetation dynamics of a Tsuga canadensis (hemlock) woodlot in central New England. Journal of Ecology 80:773-786.

Frelich, L. E., R. R. Calcote, M. B. Davis, and J. Pastor. 1993. Patch formation and maintenance in an old-growth hemlock-hardwood forest. Ecology 74:513-527.

Fuller, J. L., D. R. Foster, J. S. McLachlan, and N. E. R. Drake. 1998. Impact of human activity on regional forest composition and dynamics in central New England. Ecosystems 1:76-95.

Henry, J. D. and J. M. A. Swan. 1974. Reconstructing forest history from live and dead material: An approach to the study of forest succession in S. W. New Hampshire. Ecology 55:772-783.

Hibbs, D. E. 1982. White pine in the transition hardwood forest. Canadian Journal of Botany 60:2046-2053.

Jackson, S. T. and A. Wong. 1994. Using forest patchiness to determine pollen source areas of closed-canopy pollen assemblages. Journal of Ecology 82:89-100.

Kelty, M. J. 1986. Developmental patterns in two hemlockhardwood stands in southern New England. Canadian Journal of Forest Research 16:885-891.

Kittredge, J. 1917. Notes on the chestnut bark disease in Petersham, Massachusetts. Harvard Forestry Club Bulletin 2:13-22.

Likens, G. E., C. T. Driscoll, and D. C. Busco. 1996. Longterm effects of acid rain: response and recovery of a forested ecosystem. Science 272:244-246.

Lorimer, C. G. and L. E. Frelich. 1989. A methodology for estimating canopy disturbance frequency and intensity in temperate forests. Canadian Journal of Forest Research 19 : 651-663.

Lorimer, C. G. and L. E. Frelich. 1994. Natural disturbance regimes in old-growth northern hardwoods: Implications for restoration efforts. Journal of Forestry 92:33-38.

Nowacki, G. J. and M. D. Abrams. 1994. Forest composition, structure, and disturbance history of the Alan Seeger Natural Area, Huntington County, Pennsylvania. Bulletin of the Torrey Botanical Club 12:277-291.

Oliver, C. D. and B. C. Larson. 1996. Forest stand dynamics. John Wiley and Sons, New York, New York, USA.

Oliver, C. D. and E. P. Stephens. 1977. Reconstruction of a mixed-species forest in central New England. Ecology 58: $562-572$.

Orwig, D. A., and D. R. Foster. 1998. Forest response to the introduced hemlock wooly adelgid in southern New Eng land, USA. Journal of the Torrey Botanical Society. 125: $60-73$.
Pacala, S. W., C. D. Canham, J. Saponara, J. A. Silander, Jr. R. K. Kobe, and E. Ribbens. 1996. Forest models defined by field measurements: Estimation, error analysis and dynamics. Ecological Monographs 66(1):1-43.

Parshall, T. 1995. Canopy mortality and stand-scale change in a northern hemlock-hardwood forest. Canadian Journal of Forest Research 25:1466-1478.

Patterson, W. A. III and A. E. Backman. 1988. Fire and disease history of forests. Pages 603-632 in B. Huntley and T. Webb III, editors. Vegetation history. Kluwer, Dordrecht, The Netherlands.

Patterson, W. A. III and D. R. Foster. 1990. "Tabernacle Pines"-The rest of the story. Journal of Forestry 88:2325.

Patterson, W. A. III and K. E. Sassaman. 1988. Indian fires in the prehistory of New England. Pages $107-135$ in G. P. Nichols, editor. Holocene human ecology in northeastern North America. Plenum, New York, New York, USA.

Peterken, G. F. 1996. Natural woodland: ecology and conservation in northern temperate regions. Cambridge University Press, Cambridge, UK.

Runkle, J. R., 1981. Gap regeneration in some old-growth forests of eastern United States. Ecology 62:1041-1051.

Russell, E. W. B. 1983. Indian-set fires in the forests of the northeastern United States. Ecology 64:78-88.

Spurr, S. H. 1950. Stand composition in the Harvard Forest. Ph.D. thesis, Yale University, New Haven, Connecticut, USA.

Szeicz, J. M, B. A. Zeeb, K. D. Bennett, and J. P. Smol. 1998. High resolution paleoecological analysis of recent disturbance in a southern Chilean Nothofagus forest. Journal of Paleolimnology 20:235-252.

ter Braak, C. J. F. 1992. CANOCO: A FORTRAN program for Canonical Community Ordination, version 3. 11. Microcomputer Power, Ithaca, New York, USA.

USDA. 1996. Proceedings of the first hemlock woolly adelgid review. S. M. Salom, T. C. Tignor, and R. C. Reardon, editors. USDA Forest Service, Morgantown, West Virginia, USA.

Westveld, M. 1956. Natural forest vegetation zones of New England. Journal of Forestry 54:332-338.

Whitney, G. G. 1984. Fifty years of change in the arboreal vegetation of Heart's Content, an old-growth hemlockwhite pine-northern hardwoods stand. Ecology 65:403408.

Whitney, G. G. 1994. From coastal wilderness to fruited plain: A history of environmental change in temperate North America from 1500 to the present. Cambridge University Press, Cambridge, UK.

Whitney, P. 1793. History of the county of Worcester. Isaiah Thomas, Worcester, Massachusetts, USA. 